\title{
Copper-indium-gallium-diselenide nanoparticles synthesized by a solvothermal method for solar cell application
}

\author{
Chuan-Sheng Chiou and Huan-Chih Penga \\ Department of Mechanical Engineering, Yuan Ze University, No.135, Far-East Rd., Chung-Li, Taoyuan 32003, Taiwan
}

\begin{abstract}
Chalcopyrite copper-indium-gallium-diselenide (CIGS) nanoparticles are useful for photovoltaic applications. In this study, the synthesis of CIGS powder was examined, and the powder was successfully synthesized using a relatively simple and convenient elemental solvothermal route. From the reactions of elemental $\mathrm{Cu}, \mathrm{In}, \mathrm{Se}$ and $\mathrm{Ga}(\mathrm{NO} 3) 3$ powders in an autoclave with ethylenediamine as a solvent, spherical CIGS nanoparticles, with diameters ranging from $20-40 \mathrm{~nm}$, were obtained using a temperature of $200^{\circ} \mathrm{C}$ for $36 \mathrm{~h}$. The structure, morphology, chemical composition and optical properties of the as-synthesized CIGS were characterized using X-ray diffraction, transmission electron microscopy, selected area electron diffraction, scanning electron microscopy, inductively coupled plasma-mass spectrometry. In this sample, the mole ratio of $\mathrm{Cu}: \mathrm{In}: \mathrm{Ga}: \mathrm{Se}$ was equal to 0.89:0.71:0.29:2.01, and the optical band gap was found to be $1.18 \mathrm{eV}$. The solar cell obtained a power conversion efficiency of 5.62\% under standard air mass 1.5 global illumination.
\end{abstract}

\section{Introduction}

The simplest scenario to stabilize $\mathrm{CO} 2$ emissions by the middle of this century is one in which photovoltaics and other renewables are used for electricity, hydrogen is used for transportation, and fossil fuels are used for residential and industrial heating [1]. Chalcopyrite semiconductors have recently attracted intense interest due to their appropriate band gaps and high absorption coefficients, which are ideal for solar cell applications. Recent studies have demonstrated efficiencies as high as $20.3 \%$ in thin-film copper-indium-gallium-diselenide (CIGS)-based solar cells [2]. Co-evaporation or sputter deposition is normally employed to fabricate the absorption layer of thin-film CIGS-based solar cells. A conventional vacuum-based process is thus required to obtain these CIGS films. However, this type of processing is complex, expensive and difficult to scale-up [3]. Many researchers have, thus, recently tried to fabricate various types of absorbers for thin-film photovoltaics using relatively simple procedures, which will make semiconductor preparation more cost-effective. The creation of diverse morphologies in different chalcogenide semiconductors has been accomplished via several methods, including solvothermal routes [4], spray pyrolysis [5], electrochemical deposition [6], sol-gel methods [7], chemical bath deposition [8] and the hot injection method[9]. The ink is made from low-cost commercially available precursors with relatively low toxicity, and the fast blading process can deposit uniform layers over large areas. Using CIGS as an initial demonstration, we made solar cells with an absorber layer that is flat, contaminant-free. As an important technique for wet chemistry, the solvothermal method has been employed for the preparation of different kinds of materials [10], due to the low temperature required, the simplicity and good yield.

In this study, CIGS nanoparticles were also synthesized using the solvothermal method at reaction temperatures in the range of $160-200^{\circ} \mathrm{C}$ for $36 \mathrm{~h}$ with the intention of synthesizing a single phase CIGS powder. The structure, morphology, chemical composition and optical properties of the nanoparticles were studied, contributing to the exploration of new photovoltaic materials.

\section{Experimental procedure}

In this method, $\mathrm{Cu}, \mathrm{In}, \mathrm{Ga}(\mathrm{NO} 3) 3$ and Se powders were used as raw materials, and ethylenediamine (EN) was used as the solvent. Analytical grade reactants of $\mathrm{Cu}$ $(0.904 \mathrm{~g})$, In (1.270 g), Ga(NO3)3 (1.878 g) and Se $(2.496 \mathrm{~g})$ powders were loaded into a $100 \mathrm{ml}$ Teflon lined autoclave, which was then filled with EN up to $50 \%$ of its total volume. The sealed autoclave was maintained at a reaction temperature in the range of $160-200^{\circ} \mathrm{C}$ for $36 \mathrm{~h}$.

After cleaning, the CIGS granulates were mixed with propanol and a cationic dispersant in a ball mill for grinding. After initial grinding with $0.1 \mathrm{~mm}$ zirconium for one hour, these zirconium beads were replaced with smaller ones $(0.05 \mathrm{~mm}$ diameter $)$ and ground for three more hours. The entire milling process was carried out with cooling by a water bath at $40^{\circ} \mathrm{C}$. After $4 \mathrm{~h}$ of milling, 
the required viscosity of $3 \sim 5 \mathrm{cP}$ was obtained for the nano-scale CIGS ink.

Using a doctor blade, the CIGS nanoparticle-ink was then coated on $3.2 \mathrm{~mm}$ thick soda-lime glass substrates containing a $350 \mathrm{~nm}$ thick molybdenum (Mo) layer. After coating, solvents were removed by placing the sample in an oven at $100^{\circ} \mathrm{C}$ for $5 \mathrm{~min}$, yielding the required dry precursor films. The Figure 1 shows the novel nontoxic selenium system used in this study this route shortens the reaction pathway for the fabrication of CIGS thin films.

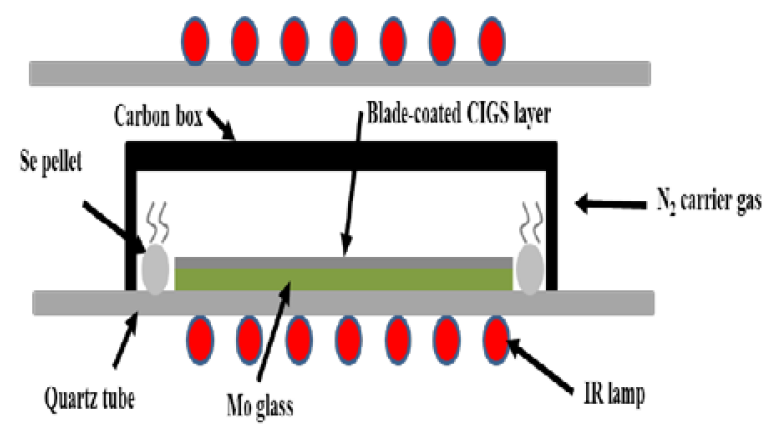

Figure 1. Schematic illustration of apparatus.

The Figure 2 show the precursor film selenization was then performed at $350^{\circ} \mathrm{C}$ for $5 \mathrm{~min}$, followed by $540^{\circ} \mathrm{C}$ for 15 min under a Se vapor environment with an N2 gas flow using a furnace with a quartz tube.

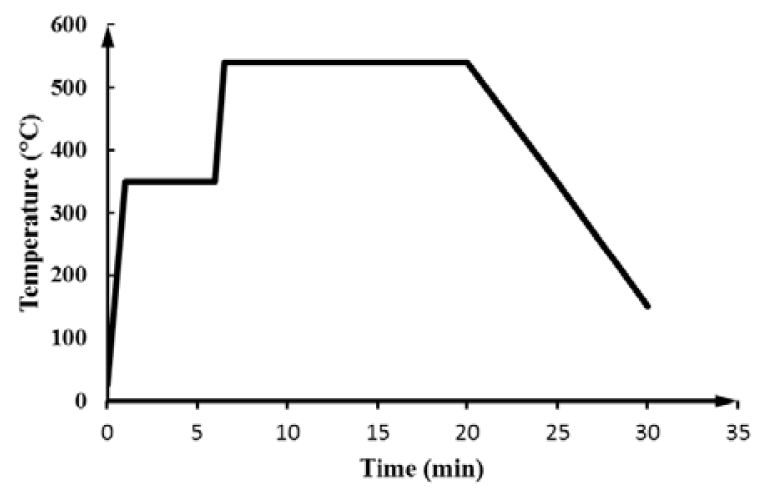

Figure 2. Temperature profile of selenization treatment.

Finally, the solar cell devices were fabricated according to the conventional configuration (Mo/CIGS/CdS/i-ZnO/n-ZnO:Al). The phase and the crystallographic structure of the products were identified using X-ray diffraction (PANalytical, X' pert pro). The particle size and morphology of the products were investigated using High-resolution transmission electron microscopy (JEOL, JEM-2100) and selected area electron diffraction. The morphologies of the samples were investigated using Scanning electron microscopy (HITACHI, S-4200). The chemical composition properties were analyzed using an Inductively coupled plasma-mass spectrometer (Perkin Elmer, SCIEX ELAN 5000)The solar cell was analyzed by measuring I-V under illumination (PV Measurement, Inc, PVM 415), with its $\mathrm{I}-\mathrm{V}$ characteristics obtained by using simulated standard test conditions of $\mathrm{AM} 1.5 \mathrm{G}$ and $1000 \mathrm{~W} / \mathrm{m} 2$ at $25^{\circ} \mathrm{C}$.

\section{Results and discussion}

\subsection{Chemical composition}

CIGS nanoparticles have previously been obtained using EN as a solvent [11]. As a strong polar solvent, EN plays an important role in the formation of CIGS nanoparticles in the synthesis process. A nucleophilic attack by EN can activate elemental selenium to form $\mathrm{Se} 2-$. In this electron transfer reaction, $\mathrm{Cu} 2+$ is also reduced to a $\mathrm{Cu}+$ ion by $\mathrm{EN}$. The $\mathrm{Cu}+$ ion with $\mathrm{EN}$ forms $[\mathrm{Cu}(\mathrm{EN}) 2]+$, which can effectively prevent the formation of binary copper chalcogenides. The reactions shown in Eqns. (1)-(5) may thus occur in the solvothermal process:

$$
\begin{gathered}
\mathrm{Se}+x(E N) \rightarrow \mathrm{Se}(\mathrm{EN}) x \\
2 \mathrm{Cu}+\mathrm{Se}(\mathrm{EN}) \mathrm{x} \rightarrow 2\left[\mathrm{Cu}(\mathrm{EN})_{2}\right]^{+}+2 \mathrm{Se}^{2-} \\
2 \mathrm{Ga}\left(\mathrm{NO}_{3}\right)_{3}+3 \mathrm{Se}^{2-} \rightarrow \mathrm{Ga}_{2} \mathrm{Se}_{3}+6\left(\mathrm{NO}_{3}\right) \\
2 \mathrm{In}+3 \mathrm{Se}(\mathrm{EN}) x \rightarrow \mathrm{In}_{2} \mathrm{Se}_{3}+x(E N) \\
20\left[\mathrm{Cu}(\mathrm{EN})_{2}\right]^{+}+7 \mathrm{In}_{2} \mathrm{Se}_{3}+3 \mathrm{Ga}_{2} \mathrm{Se}_{3}+5 \mathrm{Se}^{2-} \\
\rightarrow 20\left[\left(\mathrm{CuIn} \mathrm{Ca}_{0.7} \mathrm{Sa}_{0.3} \mathrm{Se}_{2}\right)\right]
\end{gathered}
$$

Stoichiometries compositions of the CIGS samples synthesized at $200^{\circ} \mathrm{C}$ were analyzed by an inductively coupled plasma-mass spectrometer. Philip Jackson et al.[4] reported that the optimal ratios were approximately 0.3 and $0.80-0.92$ for $\mathrm{Ga} /(\mathrm{In}+\mathrm{Ga})$ and $\mathrm{Cu} /(\mathrm{In}+\mathrm{Ga})$, respectively. A constant heating temperature of $200^{\circ} \mathrm{C}$ for $36 \mathrm{~h}$ was considered optimal for the samples since the resulting mole ratios were 0.29 for $\mathrm{Ga} /(\mathrm{In}+\mathrm{Ga})$ and 0.90 for $\mathrm{Cu} /(\mathrm{In}+\mathrm{Ga})$. The sample prepared at this temperature formed a CIGS film with a Cu:In:Ga:Se mole ratio of $0.89: 0.71: 0.29: 2.01$ compared to the $1: 0.7: 0.3: 2$ reported earlier[12].

\subsection{Structural characterization}

Figure 3 presents the XRD patterns of samples that were synthesized at various temperatures $\left(160^{\circ} \mathrm{C}, 180^{\circ} \mathrm{C}\right.$ and $200^{\circ} \mathrm{C}$ ), with a holding time of $36 \mathrm{~h}$. XRD measurements were made by scanning the diffraction angles from $20^{\circ}$ to $60^{\circ}$, using a grazing angle of incidence of $1^{\circ}$.

The XRD patterns show the variance in a crystal structure under different temperatures. For a temperature of $160^{\circ} \mathrm{C}$, the crystalline structures of CIGS and Se show many diffraction peaks at (112), (220)/(204), (312)/(116) and $(210) /(211)$. For temperatures below $180^{\circ} \mathrm{C}$, the crystalline structures of CIGS, InSe and $\mathrm{CuSe} 2$ display many diffraction peaks at (112), (220)/(204), (312)/(116), (110) and (210)/(211). 


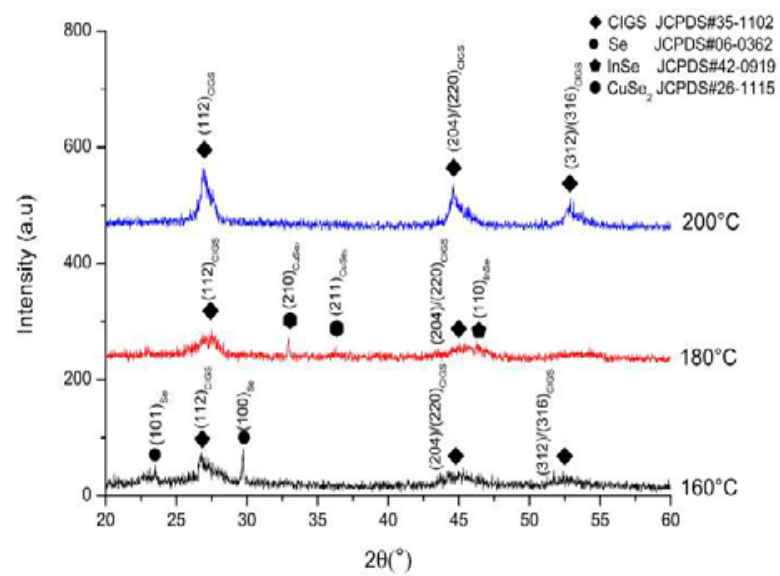

Figure 3. XRD patterns of samples that were synthesized with various temperatures of $160^{\circ} \mathrm{C}, 180^{\circ} \mathrm{C}$ and $200^{\circ} \mathrm{C}$ with holding time of $36 \mathrm{~h}$.

Furthermore, the XRD patterns show that a secondary phase exists at $160^{\circ} \mathrm{C}$ and $180^{\circ} \mathrm{C}$. This decreases the capacity of EN to chelate with $\mathrm{In} 3+$ and $\mathrm{Ga} 3+$ at a low temperature. At a higher temperature of $200^{\circ} \mathrm{C}$, the crystalline structures of CIGS shows many diffraction peaks at (112), (220)/(204) and (312)/(116). A secondary phase does not exist because the In $2 \mathrm{Se} 3$ and Ga2Se3 dissolved it. There was a $[\mathrm{Cu}(\mathrm{EN}) 2]+$ reaction under high temperature, and then, near-stoichiometries chalcopyrite structured CIGS nanoparticles were obtained.

According to the Joint Committee of Powder Diffraction Standard (JCPDS) card number 00-035-1102, the optimal angles for $\mathrm{Cu}(\mathrm{Ga} 0.3 \operatorname{In} 0.7) \mathrm{Se} 2$, with $2 \theta$ of (112), (220)/(204) and (312)/(116) are $26.89^{\circ}, 44.64^{\circ}$ and $52.94^{\circ}$, respectively. As seen in Figure 3, this corresponds well to the $2 \theta$ data from the sample synthesized at a temperature of $200^{\circ} \mathrm{C}$, with angles of $26.89^{\circ}, 44.64^{\circ}$ and $52.94^{\circ}$, respectively.

The full width at half the maximum (FWHM) of the (112)-peak of the CIGS samples synthesized at various reduction temperatures. As is well known, the FWHM corresponds to the reduction of point defects and grain growth [13]. For the sample synthesized at a heating temperature of $200^{\circ} \mathrm{C}$ for $36 \mathrm{~h}$, the peak of the preferred orientation (112) has a smaller FWHM $\left(0.82^{\circ}\right)$ and a larger grain size than those of the other samples. Analysis of the XRD patterns reveals that this sample is highly crystallized, and its $\mathrm{Cu} /(\mathrm{In}+\mathrm{Ga})$ ratio is 0.90 .

Figures 4 (a) and (b) show the TEM micrograph and SAED image of the sample synthesized at $200^{\circ} \mathrm{C}$ with a holding time of $36 \mathrm{~h}$. Figure 4 (a) shows a TEM micrograph of large agglomerates of CIGS nanoparticles. The CIGS nanoparticles are slightly dispersed, with some overlap. This confirms that spherical nanoparticles with diameters in the range of $20-40 \mathrm{~nm}$ are obtained from a reaction at $200^{\circ} \mathrm{C}$ for $36 \mathrm{~h}$. Moreover, the SAED image in Figure 4 (b) matches the structure of the CIGS, as indicated by the diffraction spots corresponding to the (112), (220)/(204) and (312)/(116) planes.

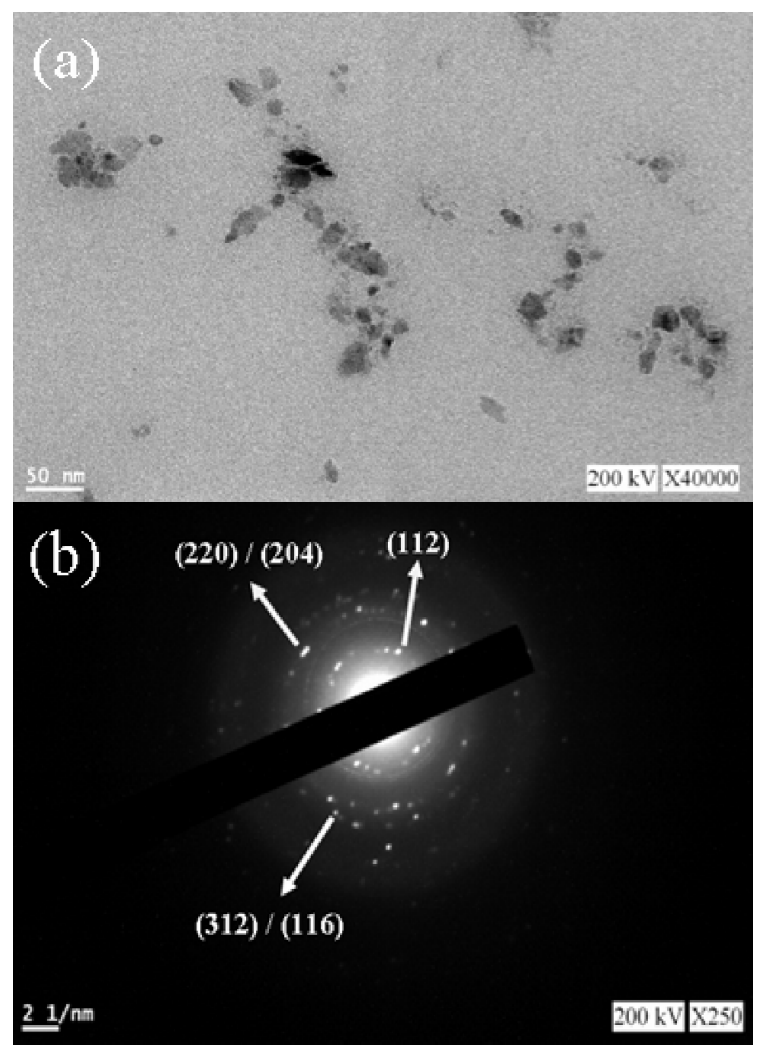

Figure 4 (a) the TEM micrograph and (b) SAED image of sample that was synthesized with a temperature of $200^{\circ} \mathrm{C}$ with holding time of $36 \mathrm{~h}$

\subsection{Photovoltaic applications}

The conventional CIGS solar cell has an $\mathrm{Al}: \mathrm{ZnO} / \mathrm{ZnO} / \mathrm{CdS} / \mathrm{CIGS} / \mathrm{Mo} /$ glass structure, and in this study, a solar cell with an active area of $0.45 \mathrm{~cm} 2$ was fabricated. Figure 5 shows a cross-section of the CIGS film observed using SEM, revealing that the thickness of the CIGS layer is $\sim 2.0 \mu \mathrm{m}$.

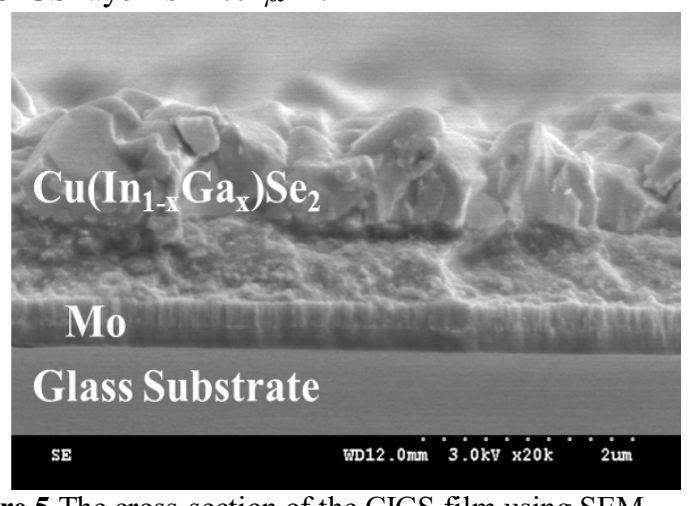

Figure 5 The cross-section of the CIGS film using SEM.

Figure 6 (a) show the cross-section of CIGS cell observed using SEM, and the Figure 6 (b) plots the illuminated $\mathrm{I}-\mathrm{V}$ characteristics of such a device, fabricated on an absorber. This device has a conversion efficiency of $5.62 \%$ (open circuit voltage $(\mathrm{Voc})=0.48 \mathrm{~V}$, current density $(\mathrm{Jsc})=27.32 \mathrm{~mA} / \mathrm{cm} 2$, fill factor $(\mathrm{FF})=$ $41.15 \%)$.

Although the Jsc of our device is very close to the $20.3 \%$ efficiency solar cell reported by ZSW, the Voc and $\mathrm{FF}$ are still inferior to those of the record cell. Based 
on a model calculation, Shunt resistance and diode ideality factor are two key factors that affect the Voc value. Low shunt resistance resulting from pin-holes, cracks, or impurities in and near the junction leads to an increase of shunt current and a decrease of Voc. Therefore, the elimination of pin-holes, cracks, or impurities is essential for the fabrication of highly efficient solar cells. In addition, high Ga content near the CIGS/CdS interface and low interfacial roughness should further improve the Voc as well. As to the series resistance of device, it is 100 times larger than the series resistance of the high efficiency solar cells[5] which results in the softness in the knee of $\mathrm{I}-\mathrm{V}$ curve and the degradation of FF and $\eta$ values. Considering the high resistance resulting from reduce the thick layer of MoSe2[4], it is reasonable to assume that the cell efficiency could be improved by a thicker Mo layer.

(a)
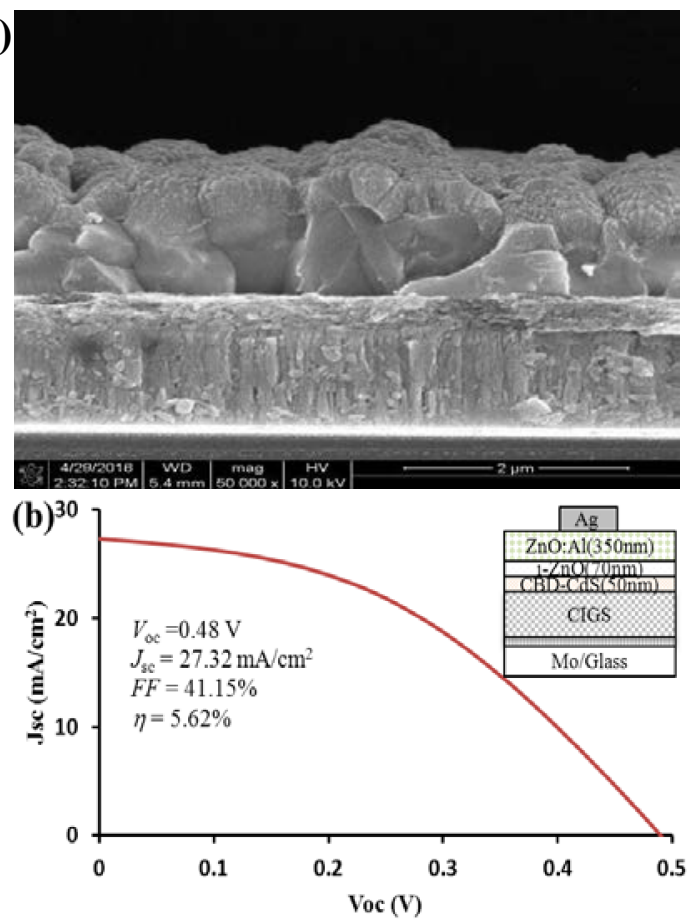

Figure 6 (a) the cross-section of the CIGS film using SEM, and (b) illuminated I-V characteristics of such a device fabricated on an absorber such a device, which was fabricated on an absorber

\section{Conclusion}

CIGS nanoparticles were synthesized through the solvothermal method at a reaction temperature of $200^{\circ} \mathrm{C}$ for $36 \mathrm{~h}$, with the intention of synthesizing a single phase CIGS powder. Near-stoichiometric chalcopyrite structured CIGS nanoparticles were obtained. The narrow FWHM of the XRD pattern and the clear crystal lattices of the CIGS nanoparticles revealed by HR-TEM indicate their high quality. This further confirmed that CIGS nanoparticles with diameters in the range of 20-40 nm were obtained. In this sample, the synthesized raw CIGS powder mole ratio of $\mathrm{Cu}: \mathrm{In}: \mathrm{Ga}: \mathrm{Se}$ was equal to 0.89:0.71:0.29:2.01. Analysis of the performance of the obtained solar cell under a standard AM1.5 G illumination revealed a conversion efficiency of $5.62 \%$. In summary, these results support the notion that CIGS nanoparticles synthesized through the solvothermal method may be useful as the absorption layer in CIGS solar cells.

\section{References}

1. T.M. Razykov, C.S. Ferekides, D. Morel, E. Stefanakos, H.S. Ullal, H.M. Upadhyaya, Solar photovoltaic electricity: Current status and future prospects, Solar Energy, 85 (2011) 1580-1608.

2. P. Jackson, D. Hariskos, E. Lotter, S. Paetel, R. Wuerz, R. Menner, W. Wischmann, M. Powalla, New world record efficiency for $\mathrm{Cu}(\mathrm{In}, \mathrm{Ga}) \mathrm{Se}_{2}$ thinfilm solar cells beyond 20\%, Progress in Photovoltaics: Research and Applications, 19 (2011) 894-897.

3. M. Kaelin, D. Rudmann, F. Kurdesau, H. Zogg, T. Meyer, A.N. Tiwari, Low-cost CIGS solar cells by paste coating and selenization, Thin Solid Films, 480-481 (2005) 486-490.

4. W.-L. Lu, Y.-S. Fu, B.-H. Tseng, Preparation and characterization of CuInSe $\mathrm{C}_{2}$ nano-particles, Journal of Physics and Chemistry of Solids, 69 (2008) $637-$ 640.

5. J.M. Peza-Tapia, A. Morales-Acevedo, M. OrtegaLópez, Electrical characterization of $\mathrm{Al}, \mathrm{Ag}$ and In contacts on $\mathrm{CuInS}_{2}$ thin films deposited by spray pyrolysis, Solar Energy Materials and Solar Cells, 93 (2009) 544-548.

6. M. Benaicha, N. Benouattas, C. Benazzouz, L. Ouahab, Effect of bath temperature and annealing on the formation of $\mathrm{CuInSe}_{2}$, Solar Energy Materials and Solar Cells, 93 (2009) 262-266.

7. P. Luo, R. Zuo, L. Chen, The preparation of $\mathrm{CuInSe}_{2}$ films by combustion method and nonvacuum spin-coating process, Solar Energy Materials and Solar Cells, 94 (2010) 1146-1151.

8. A. Wangperawong, J.S. King, S.M. Herron, B.P. Tran, K. Pangan-Okimoto, S.F. Bent, Aqueous bath process for deposition of $\mathrm{Cu}_{2} \mathrm{ZnSnS}_{4}$ photovoltaic absorbers, Thin Solid Films, 519 (2011) 2488-2492.

9. A. Shavel, J. Arbiol, A. Cabot, Synthesis of Quaternary Chalcogenide Nanocrystals: Stannite $\mathrm{Cu}_{2} \mathrm{Zn}_{\mathrm{x}} \mathrm{Sn}_{\mathrm{y}} \mathrm{Se}_{1+\mathrm{x}+2 \mathrm{y}}$, Journal of the American Chemical Society, 132 (2010) 4514-4515.

10. Y.-L. Zhou, W.-H. Zhou, Y.-F. Du, M. Li, S.-X. Wu, Sphere-like kesterite $\mathrm{Cu}_{2} \mathrm{ZnSnS}_{4}$ nanoparticles synthesized by a facile solvothermal method, Materials Letters, 65 (2011) 1535-1537.

11. Y.G. Chun, K.H. Kim, K.H. Yoon, Synthesis of $\mathrm{CuInGaSe}_{2}$ nanoparticles by solvothermal route, Thin Solid Films, 480-481 (2005) 46-49.

12. C. Suryanarayana, E. Ivanov, R. Noufi, M.A. Contreras, J.J. Moore, Phase selection in a mechanically alloyed Cu2013;In-Ga-Se powder mixture, Journal of Materials Research, 14 (1999) 377-383.

13. T. Schlenker, M.L. Valero, H.W. Schock, J.H. Werner, Grain growth studies of thin $\mathrm{Cu}(\mathrm{In}, \mathrm{Ga}) \mathrm{Se}_{2}$ films, Journal of Crystal Growth, 264 (2004) 178-183. 